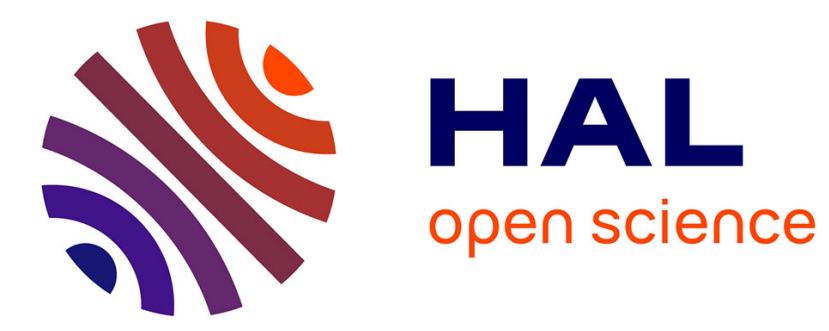

\title{
Study of the neutrino electromagnetic properties with prototype of BOREXINO detector
}

\author{
H.O. Back, M. Balata, A. de Bari, T. Beau, A. de Bellefon, G. Bellini, J. \\ Benziger, S. Bonetti, C. Buck, B. Caccianiga, et al.
}

\section{- To cite this version:}

H.O. Back, M. Balata, A. de Bari, T. Beau, A. de Bellefon, et al.. Study of the neutrino electromagnetic properties with prototype of BOREXINO detector. Physics Letters B, 2003, 563, pp.35-47. in2p300013677

\section{HAL Id: in2p3-00013677 https://hal.in2p3.fr/in2p3-00013677}

Submitted on 8 Jul 2003

HAL is a multi-disciplinary open access archive for the deposit and dissemination of scientific research documents, whether they are published or not. The documents may come from teaching and research institutions in France or abroad, or from public or private research centers.
L'archive ouverte pluridisciplinaire HAL, est destinée au dépôt et à la diffusion de documents scientifiques de niveau recherche, publiés ou non, émanant des établissements d'enseignement et de recherche français ou étrangers, des laboratoires publics ou privés. 


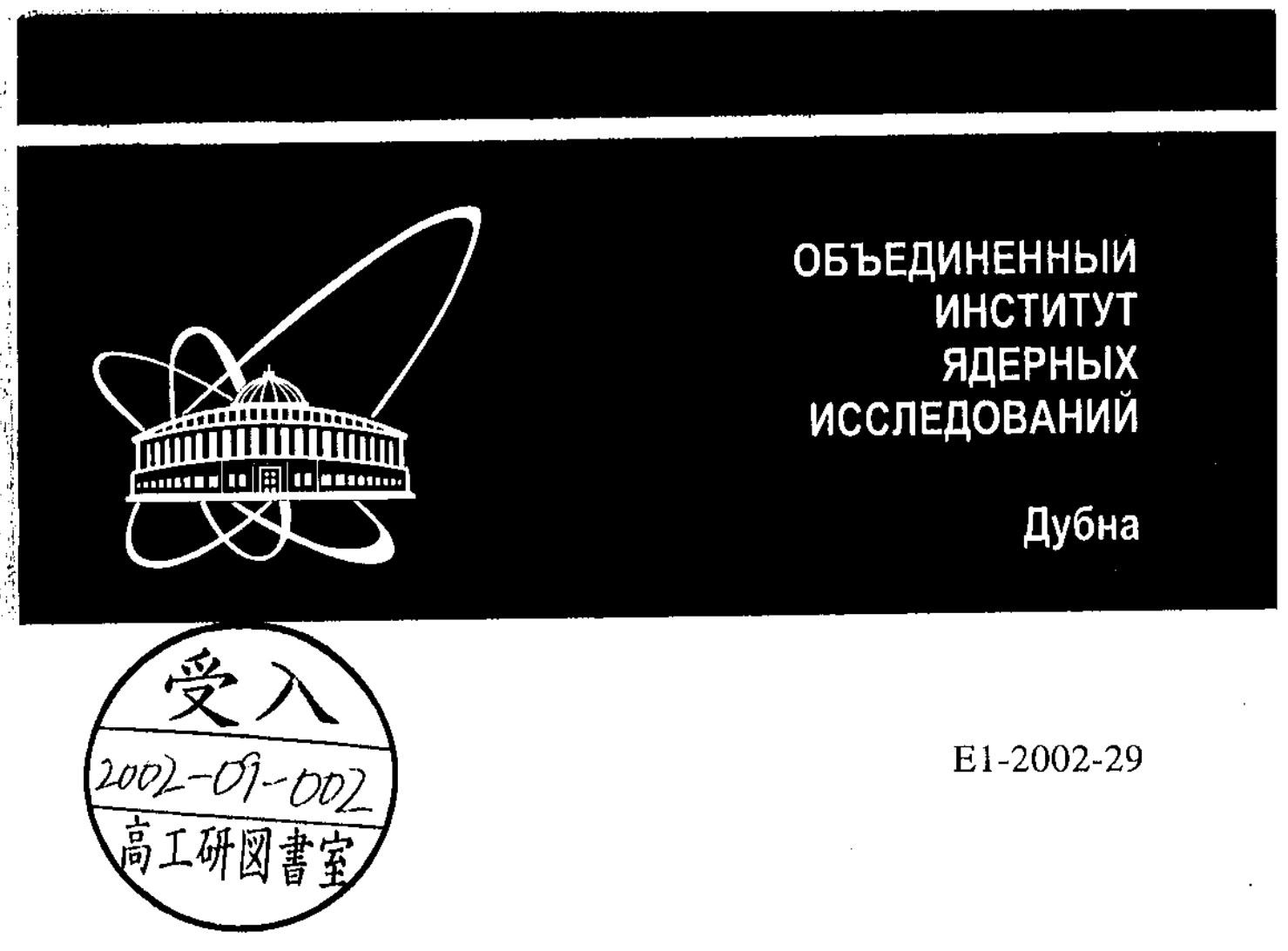

STUDY OF THE NEUTRINO ELECTROMAGNETIC PROPERTIES WITH PROTOTYPE OF BOREXINO DETECTOR

Submitted to «Physics Letters B»

\section{2}




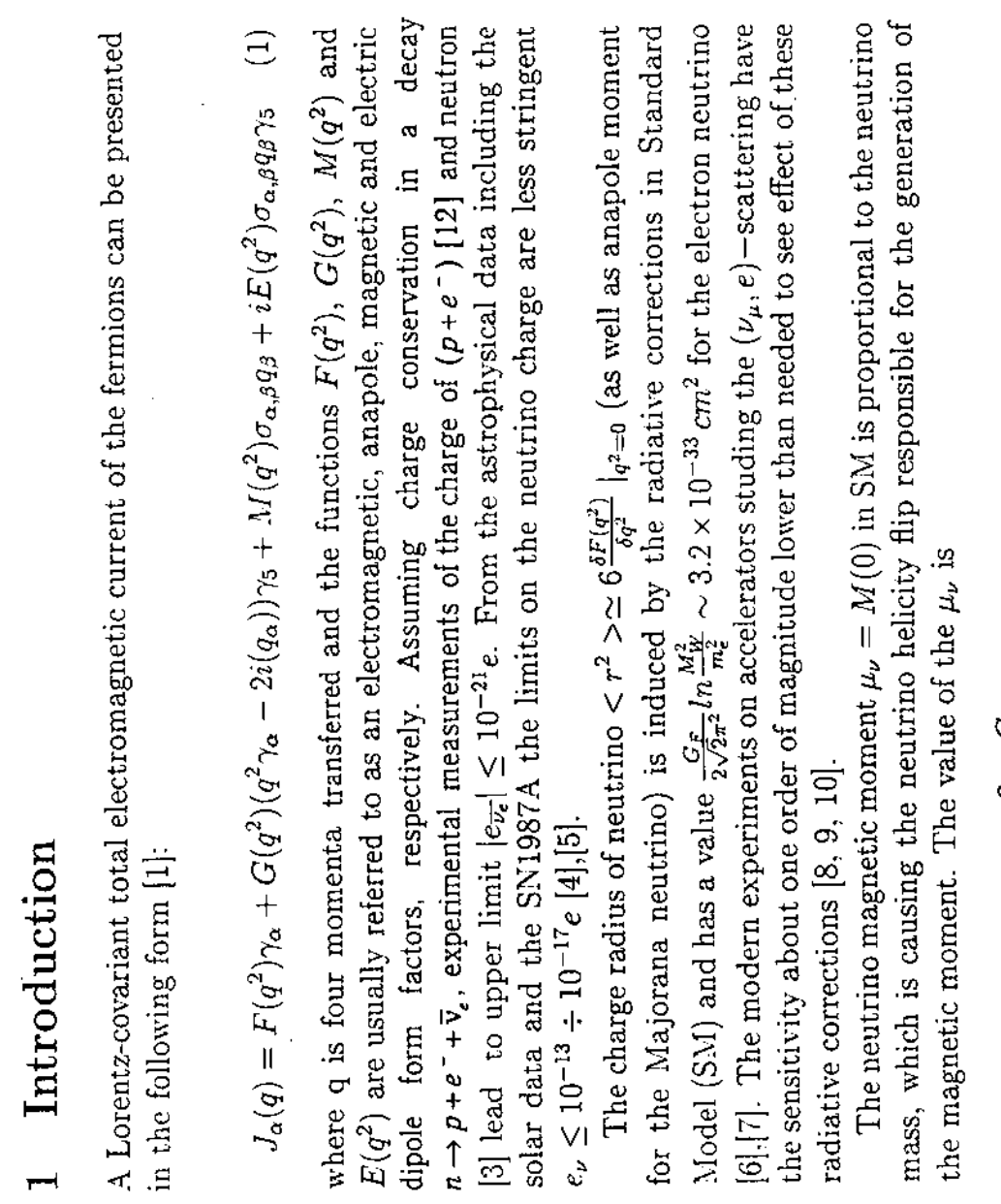

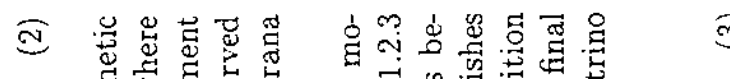

$\sqrt{3}$

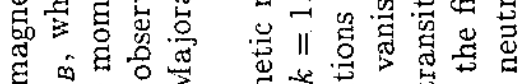

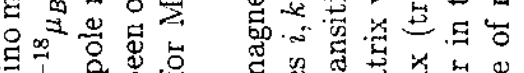

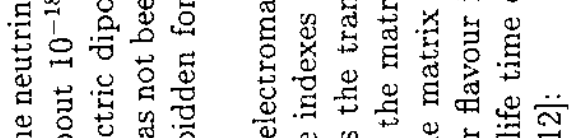

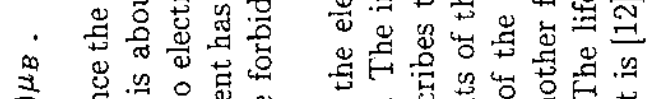

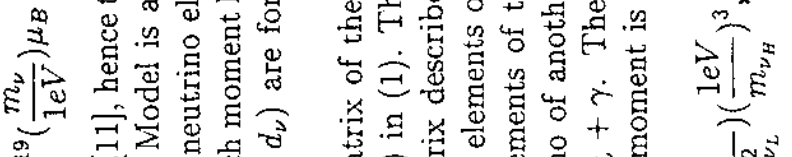

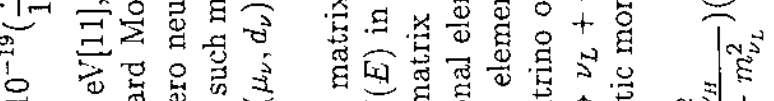

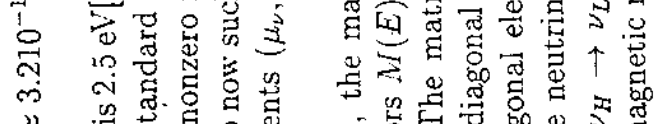

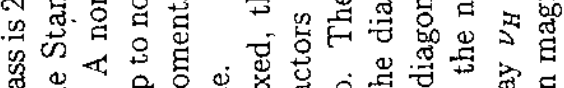

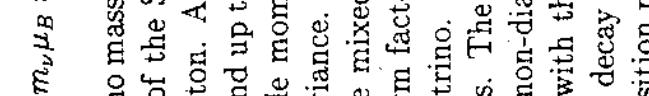

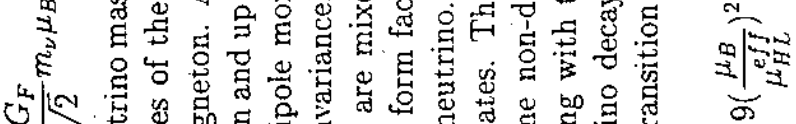

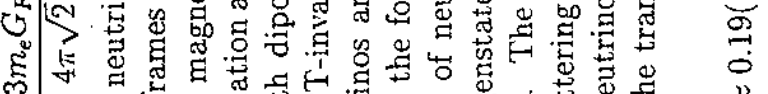

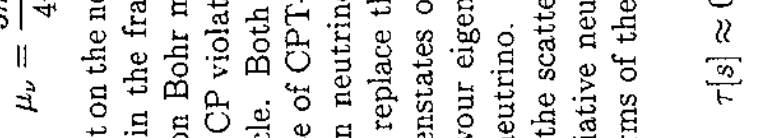

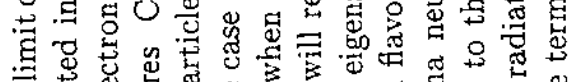

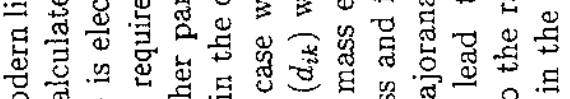

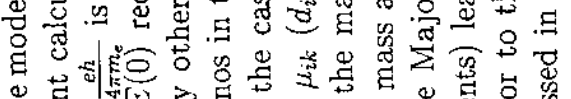

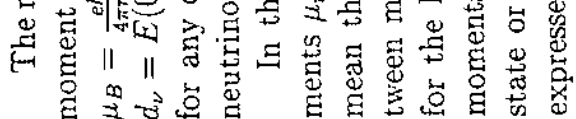

है।

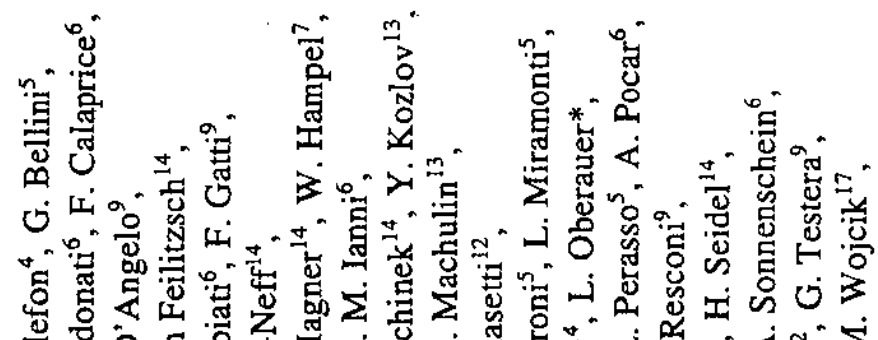

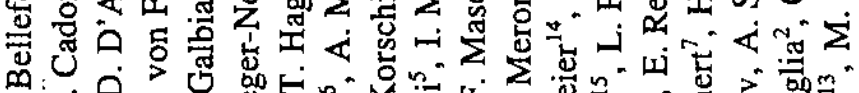

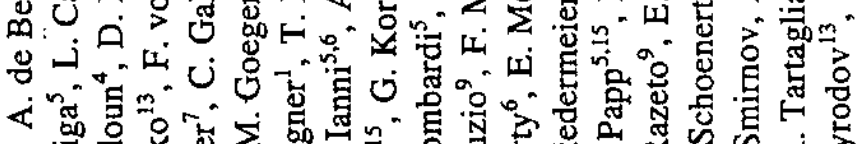

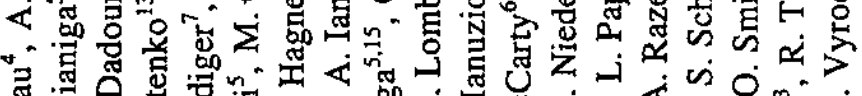

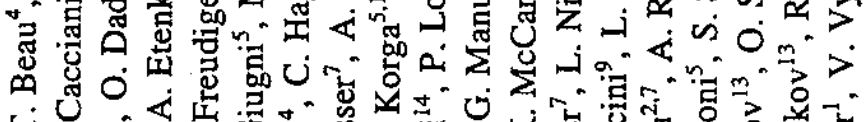

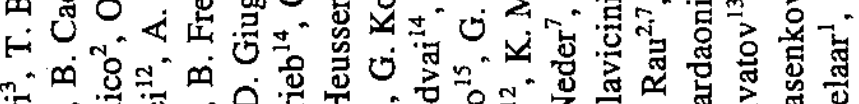

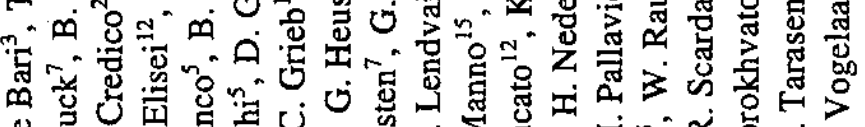

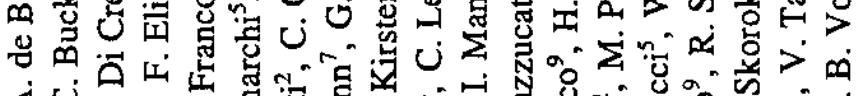

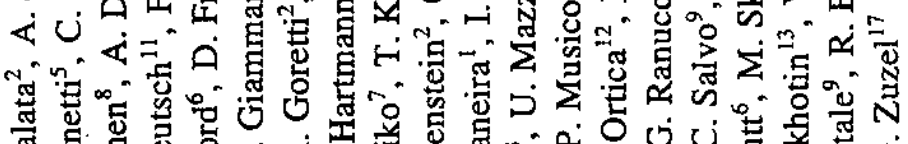

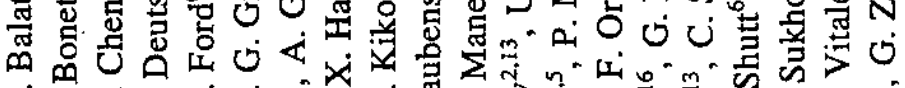

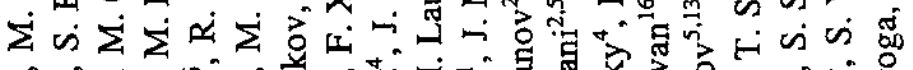

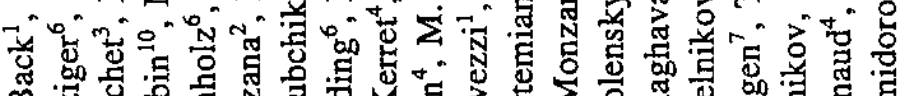

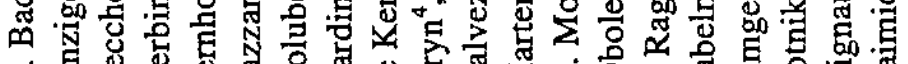

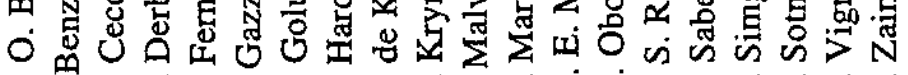

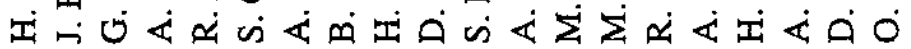

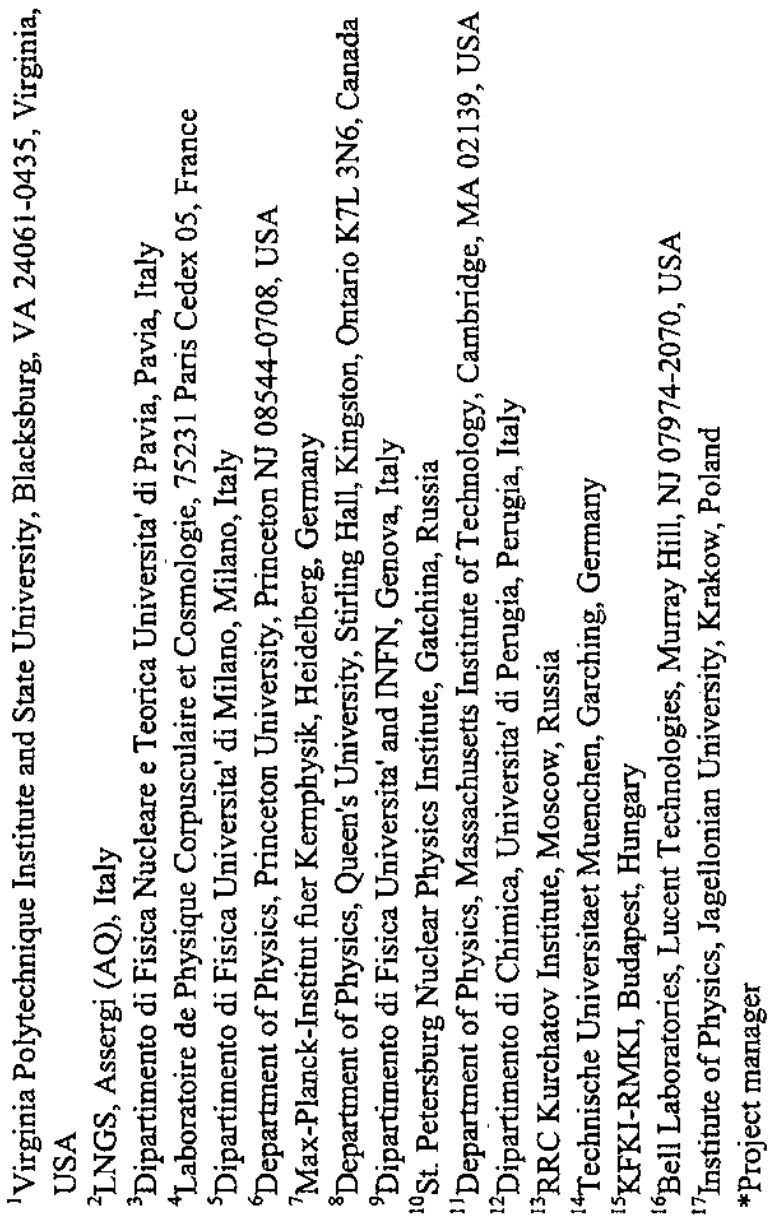




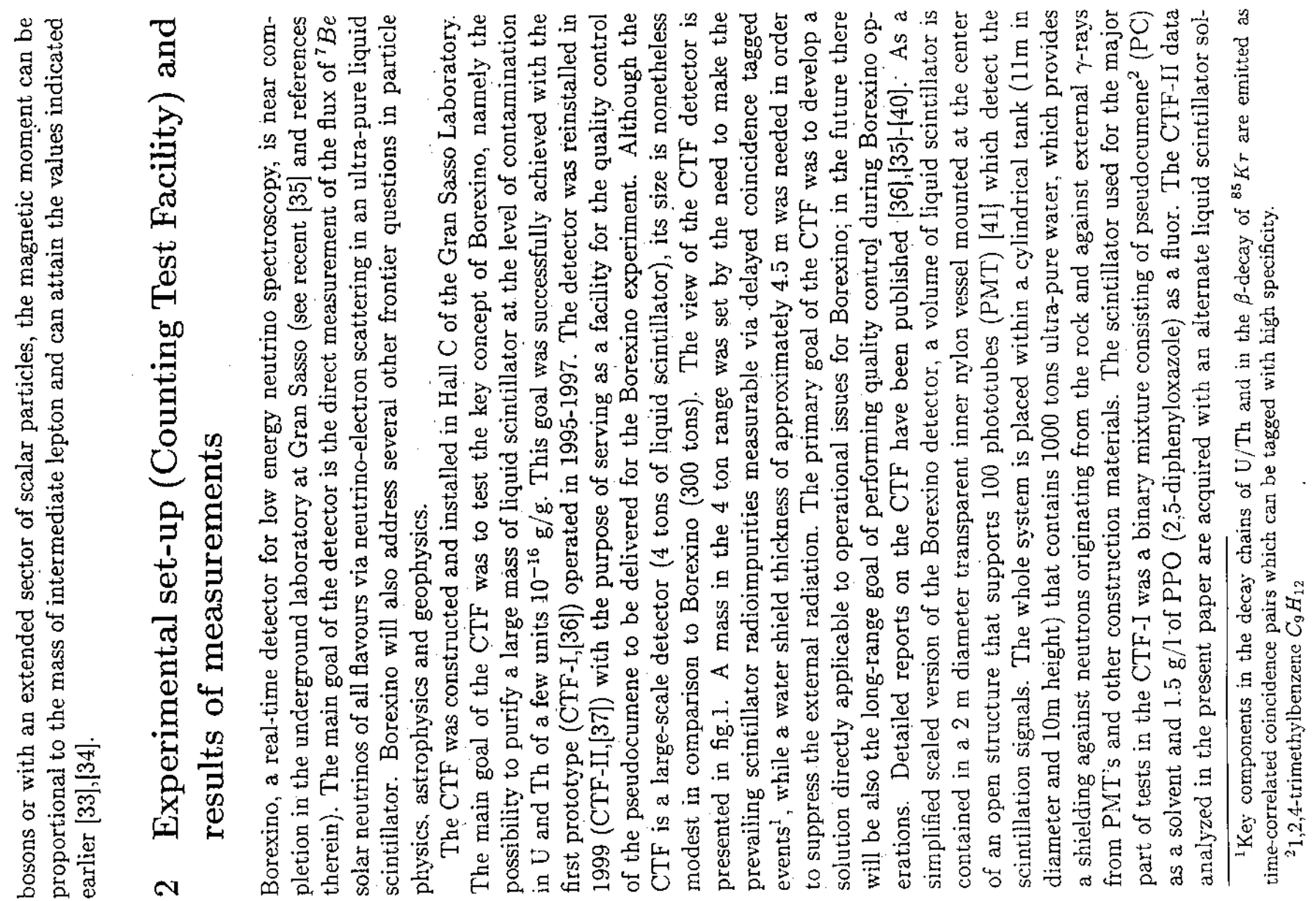

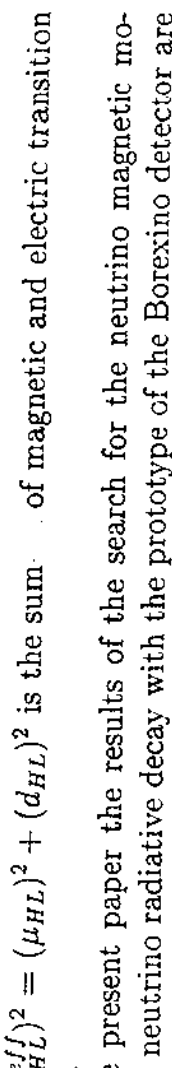

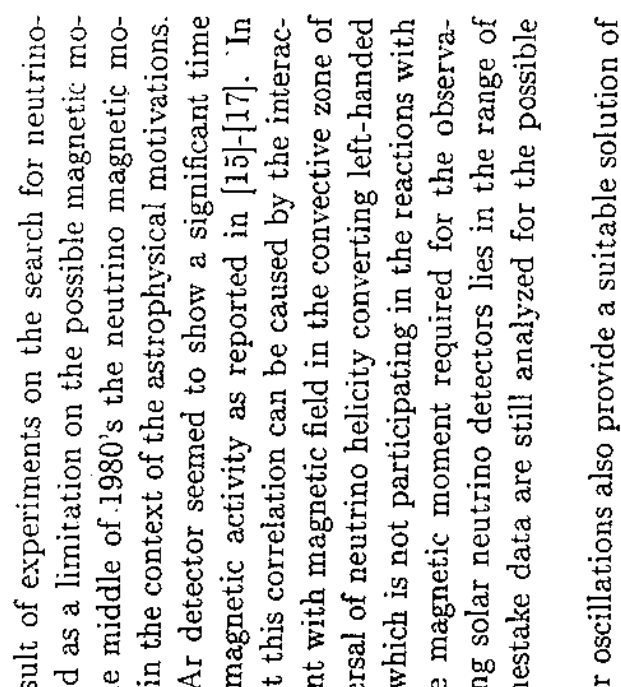

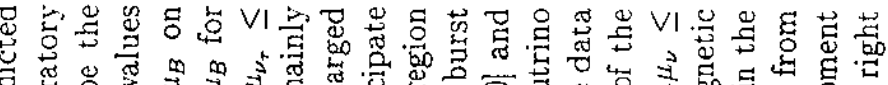

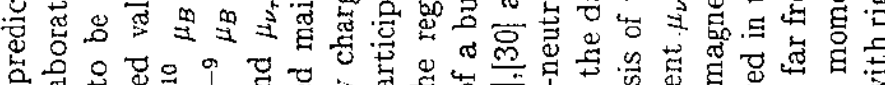

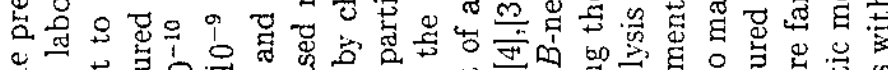

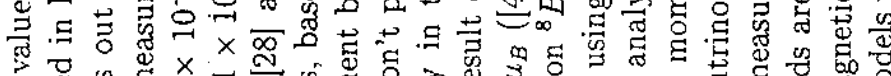

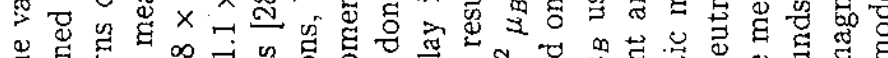

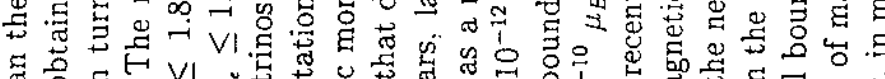
영

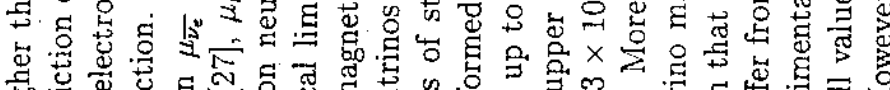

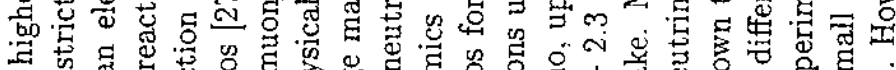

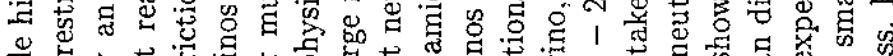

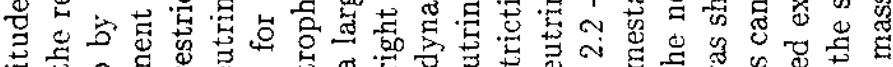

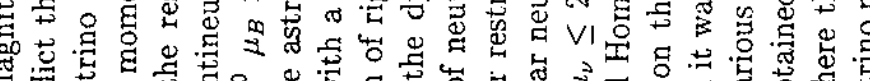

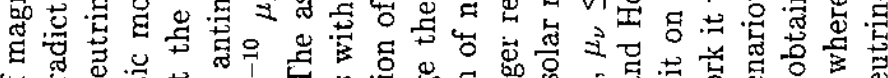

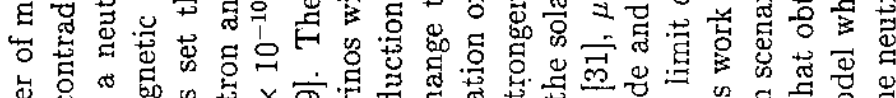

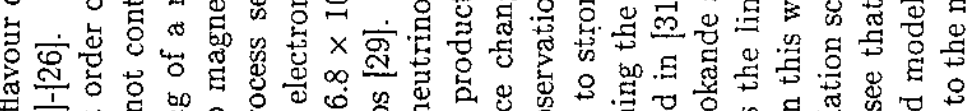

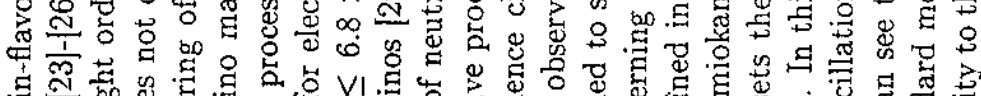

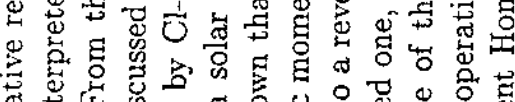

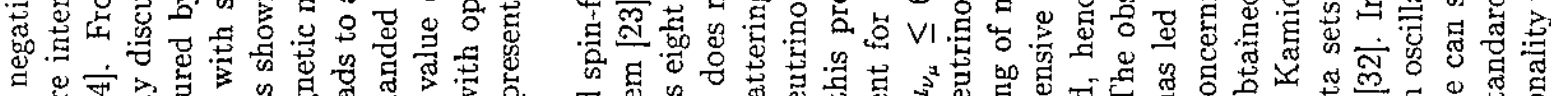

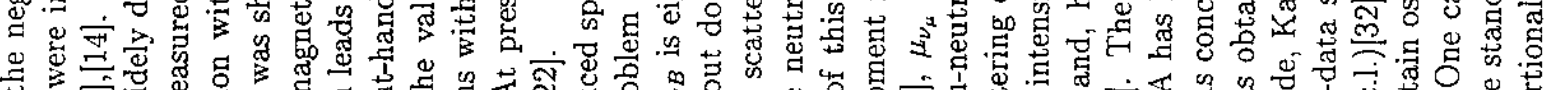

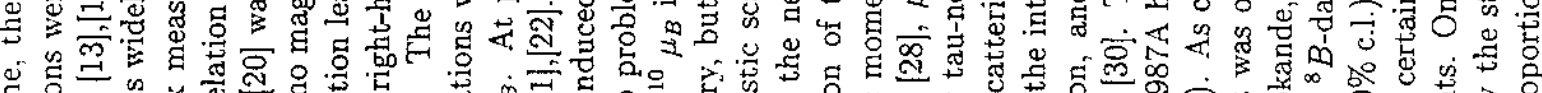
. 等

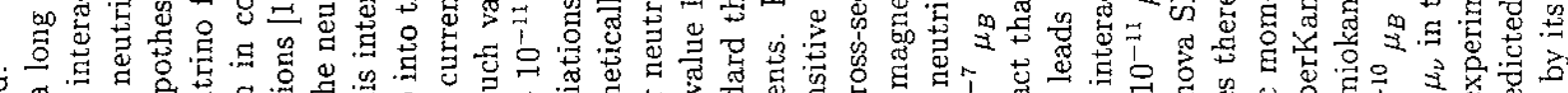

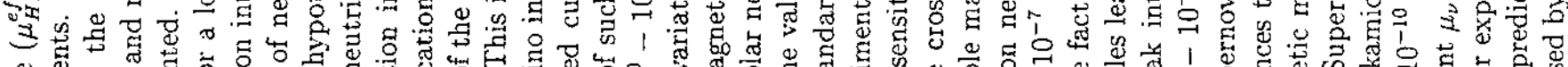

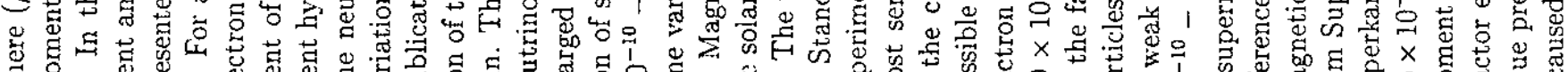

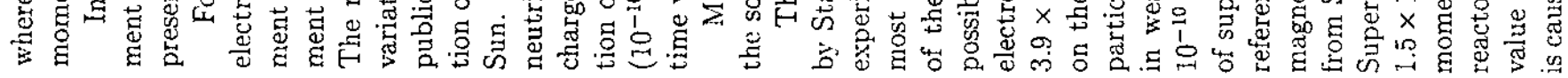




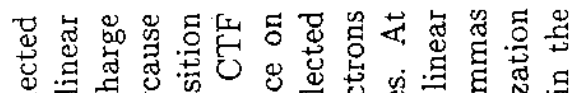
过品

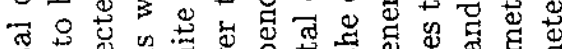

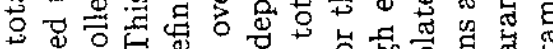

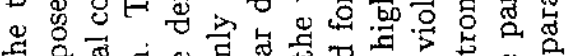

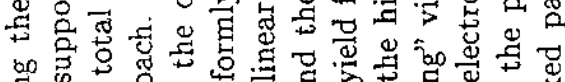

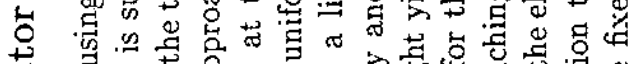

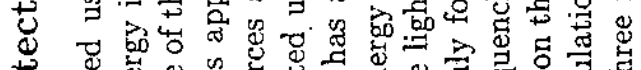

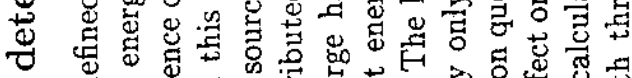

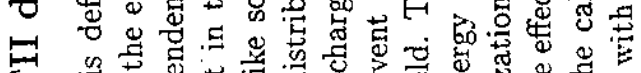
ம

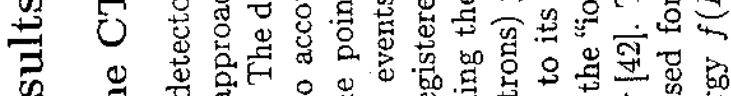
O

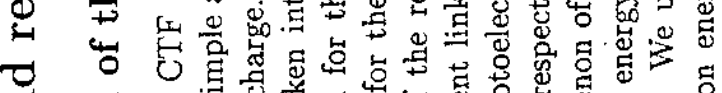
ส 5 क

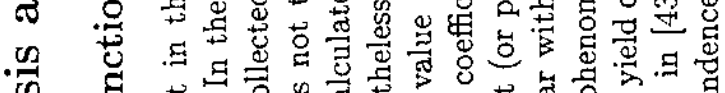

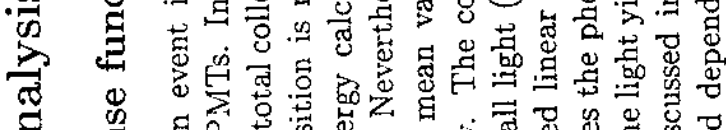

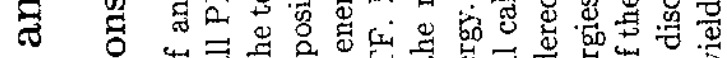
๙ 0 范

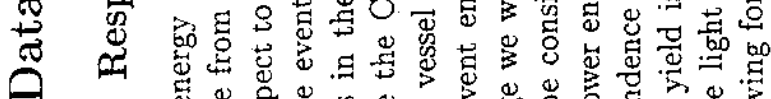
の

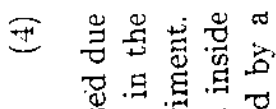

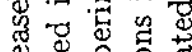

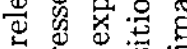

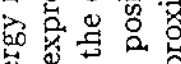 ․ㅕㅇ}

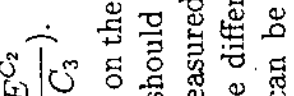

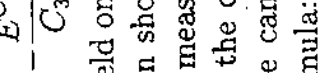

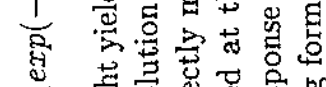

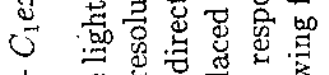

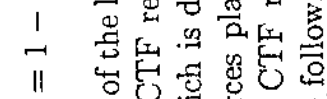

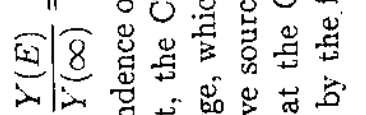
1

III

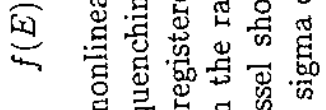

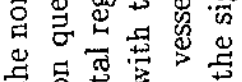

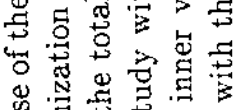
承寻灵

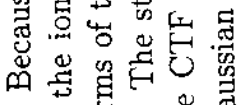
果专

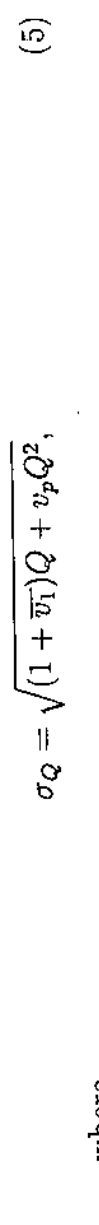

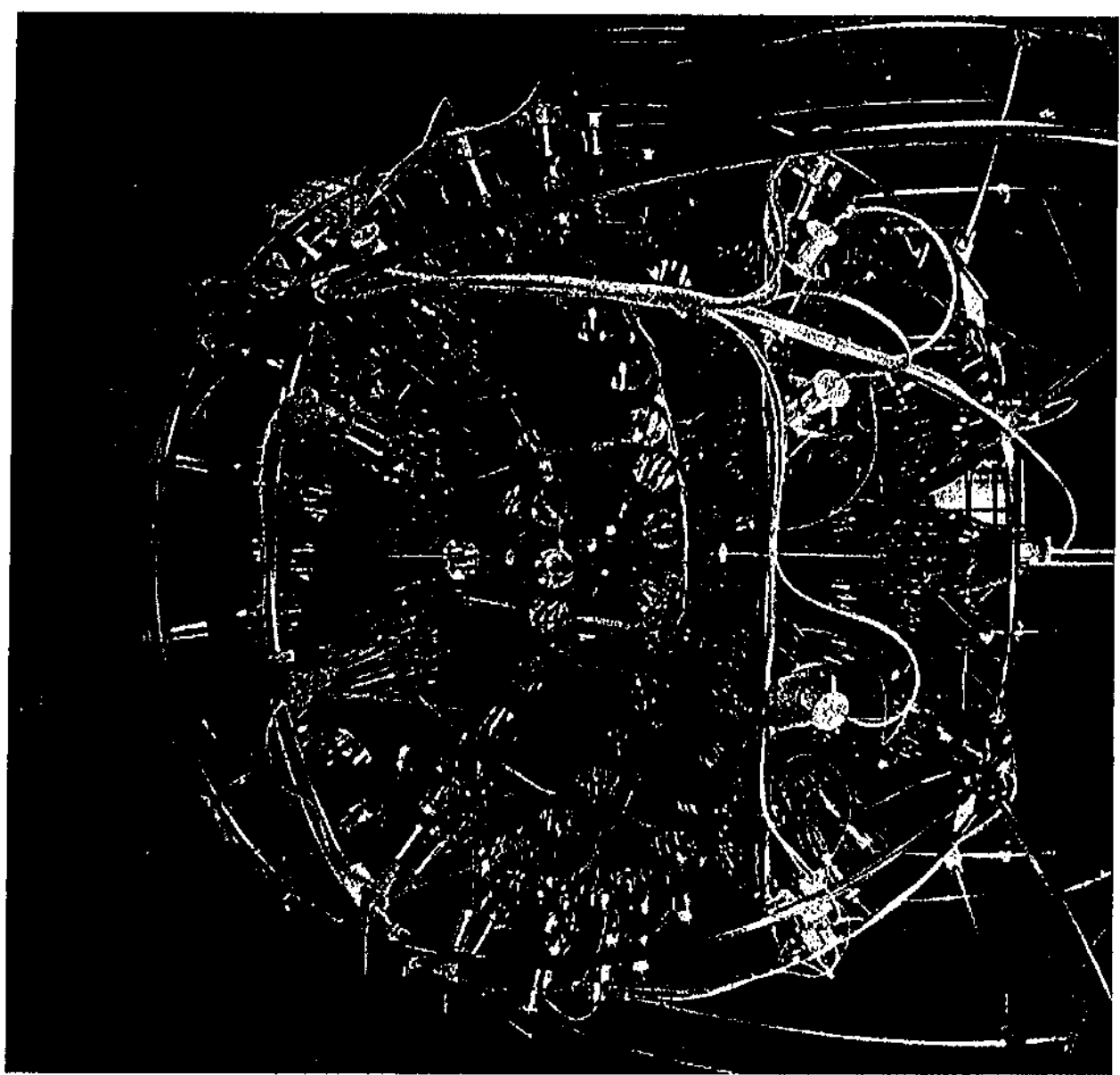




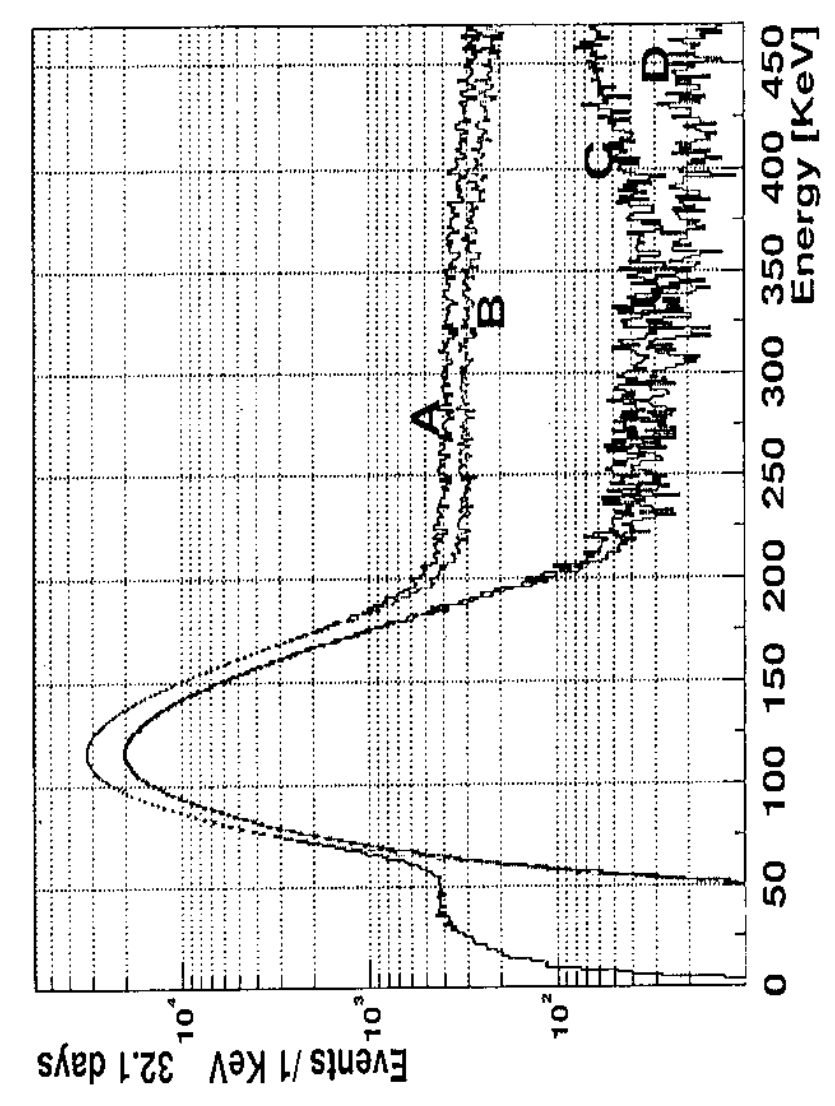

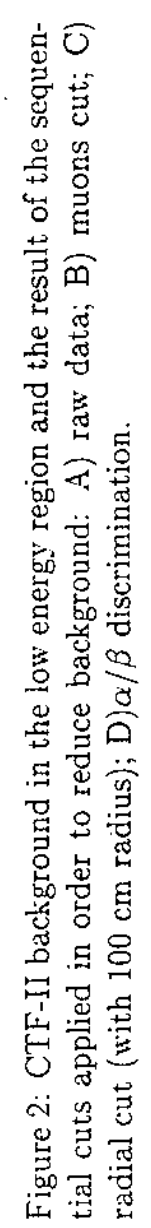

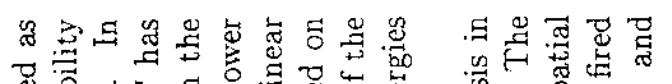

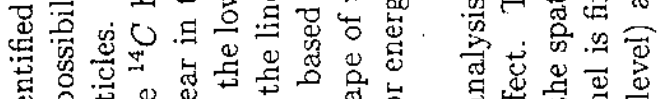

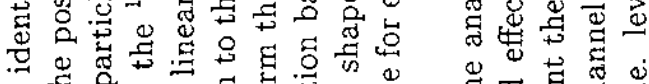

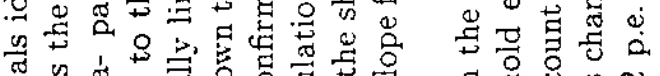

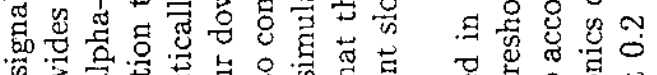

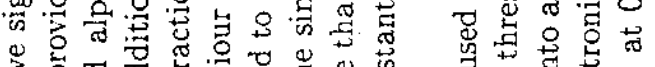

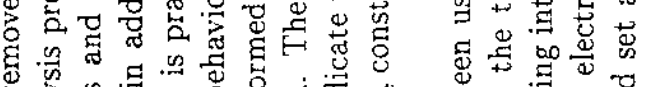

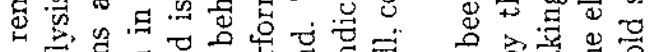

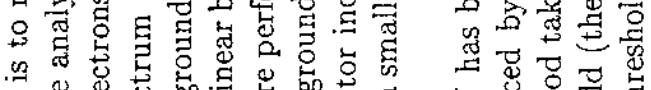

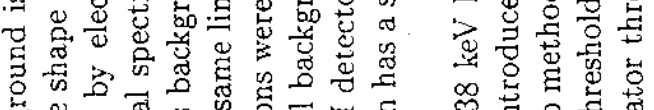

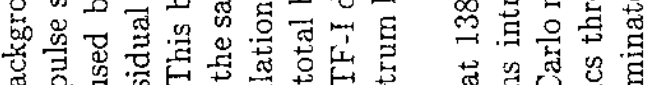

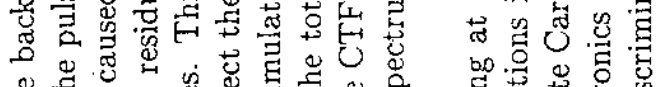

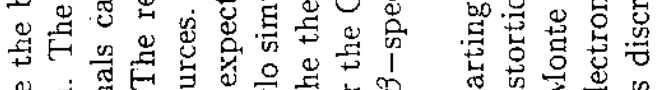

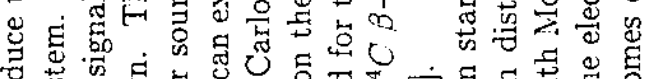

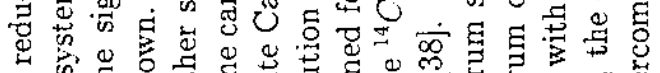

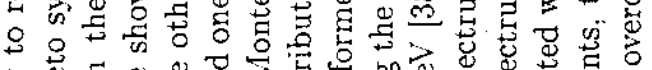

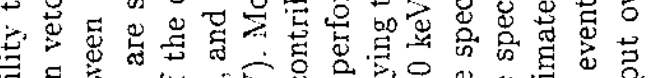

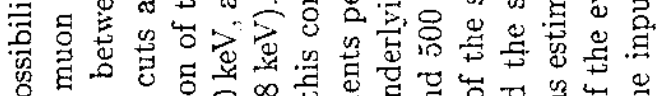

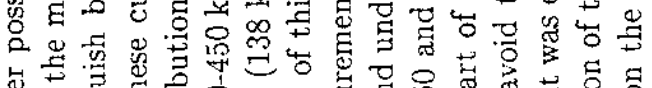

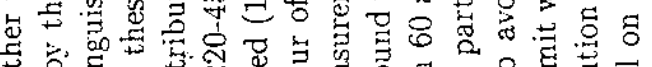

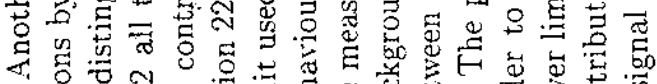

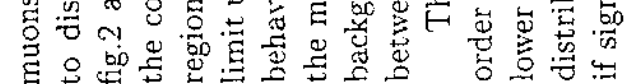

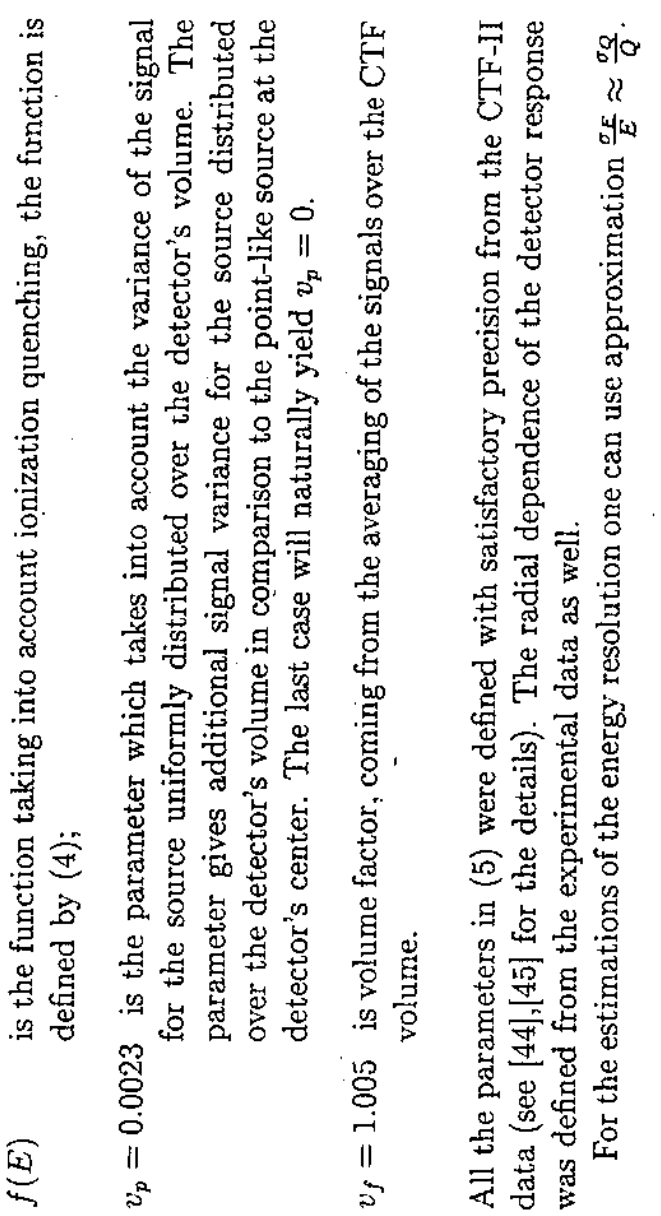

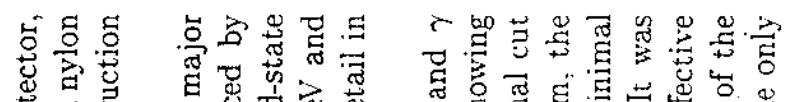

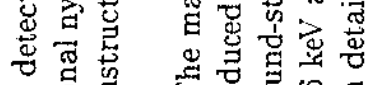

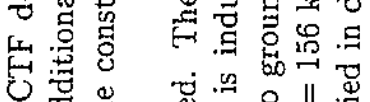

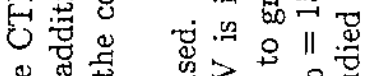

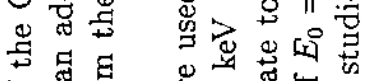

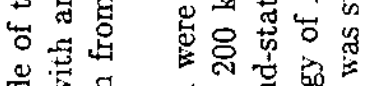

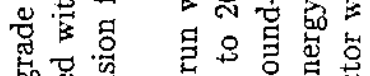

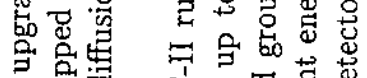

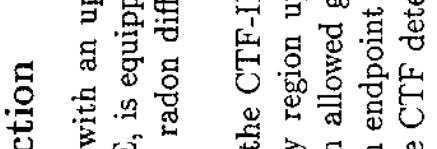

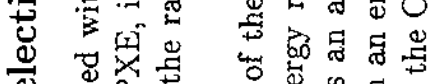
क

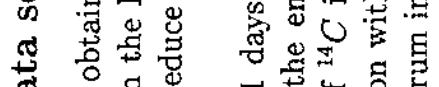

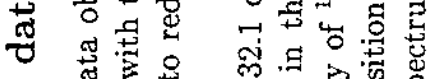
प वृ

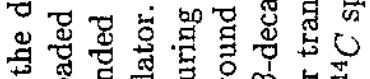

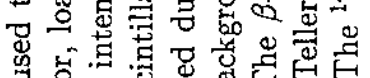

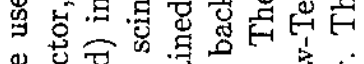

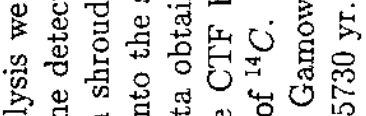

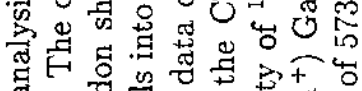

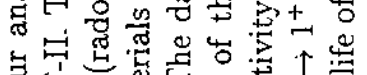

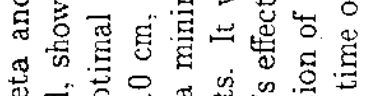

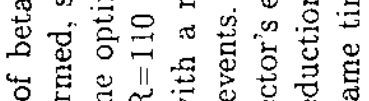

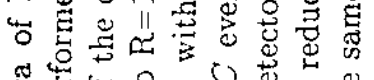

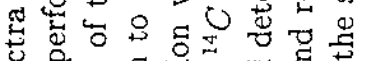

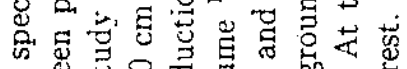

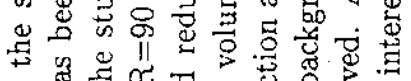

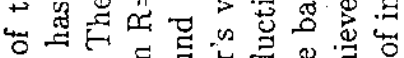

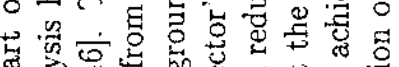

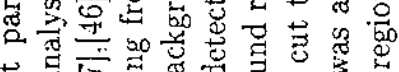

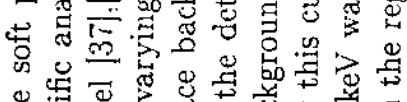
富

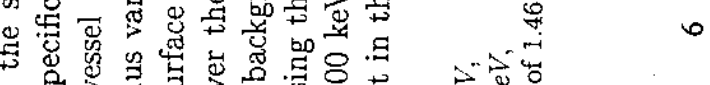

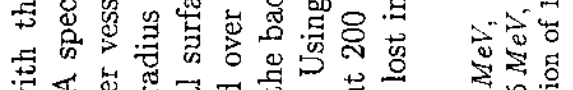

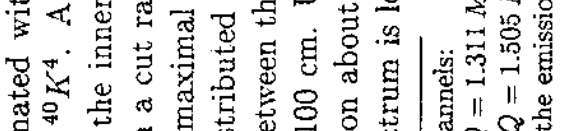

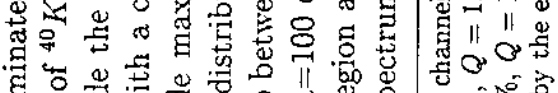

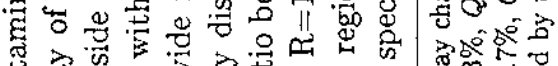

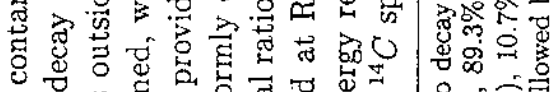
\% ๘ 要

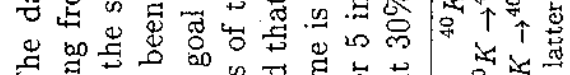
ヘ 


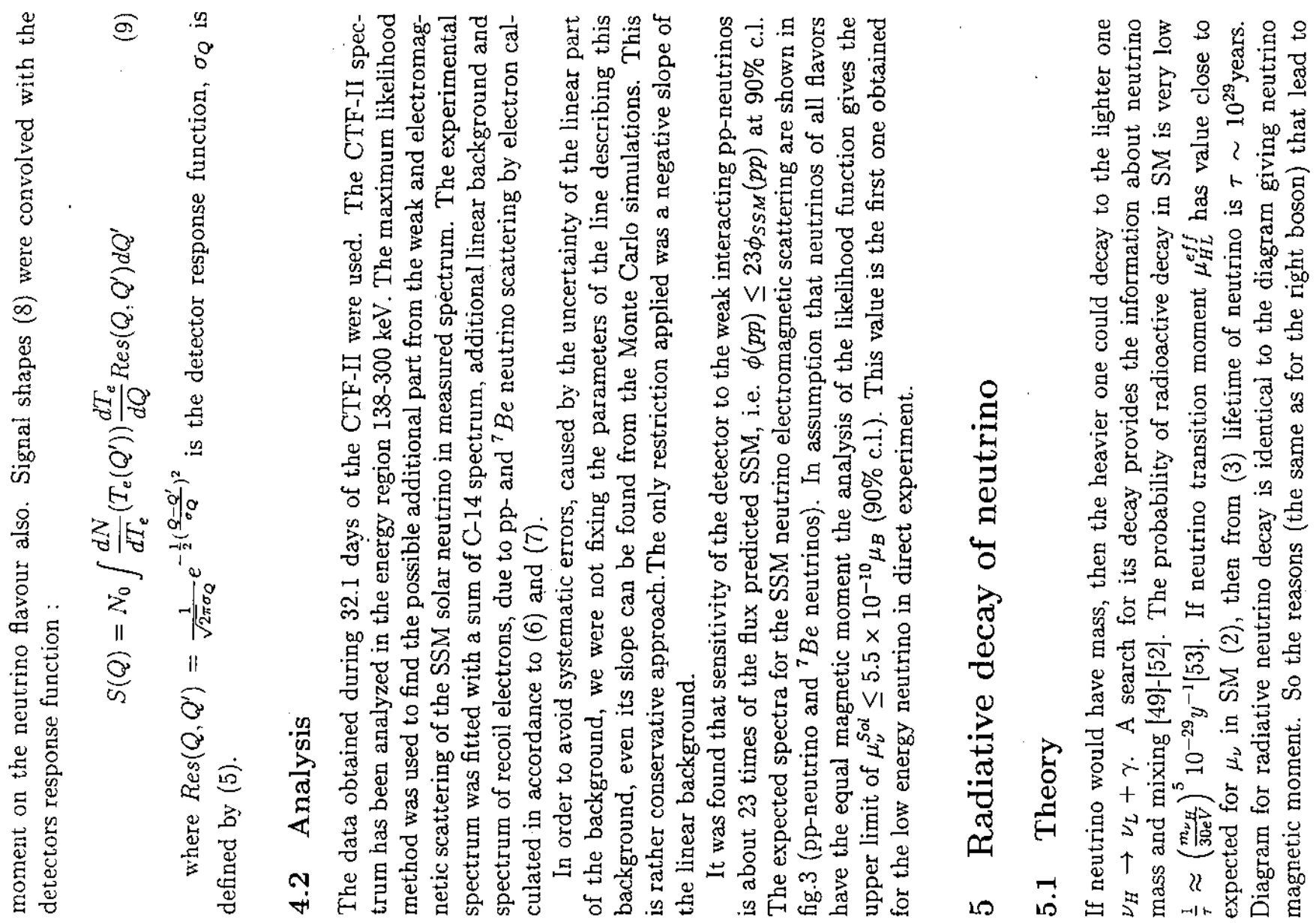

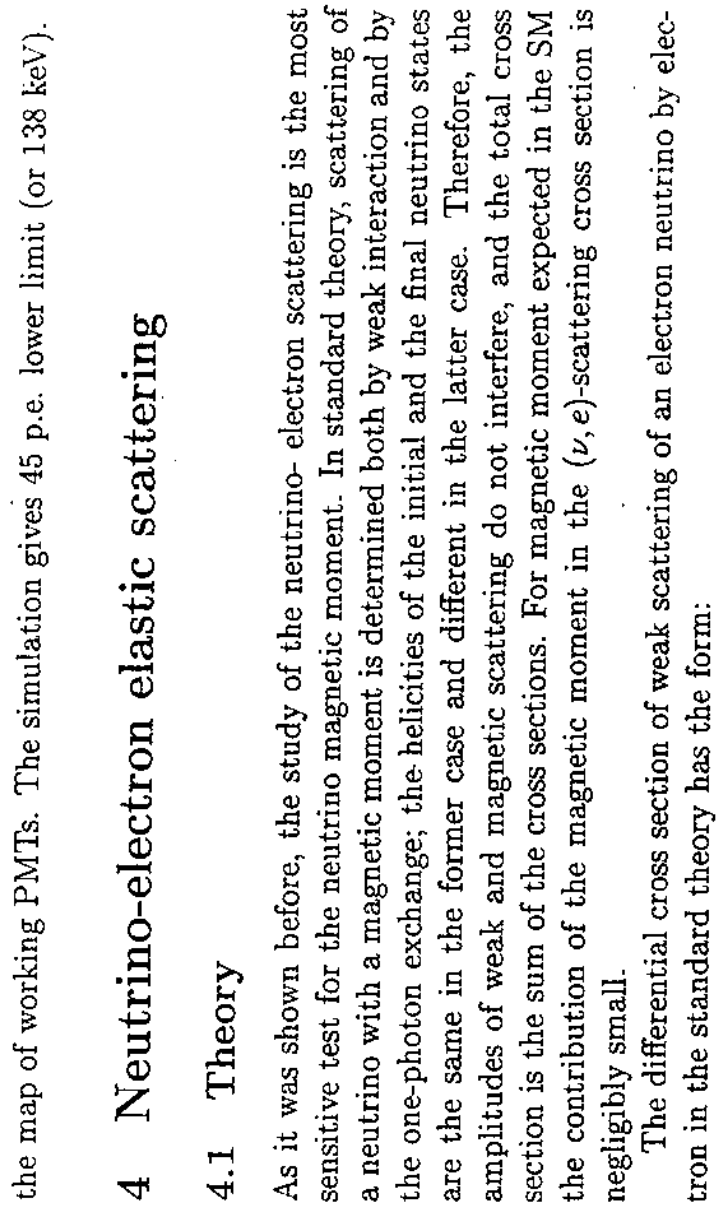

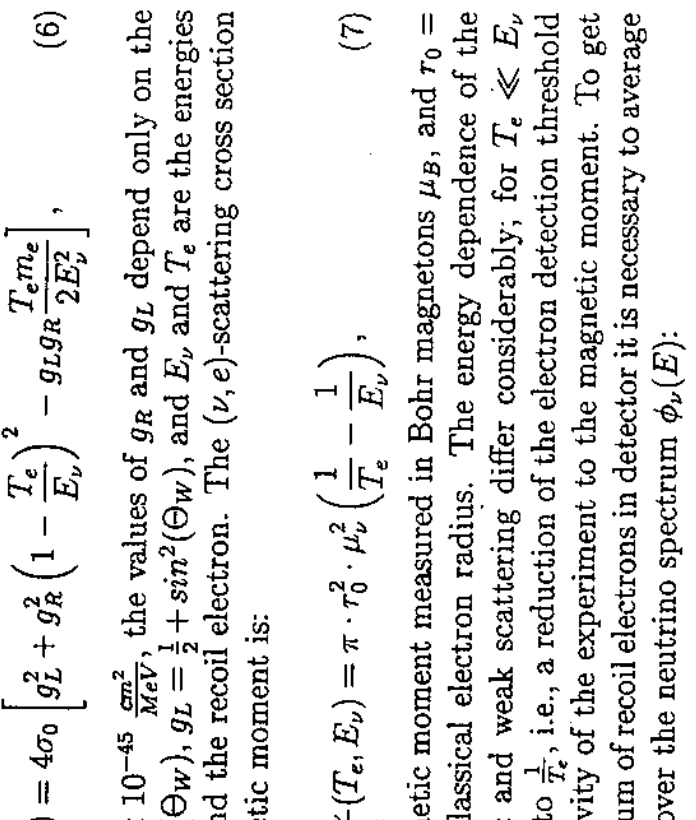

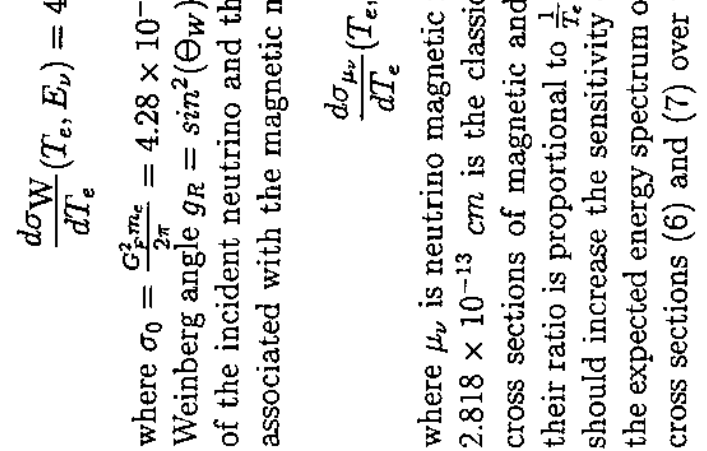

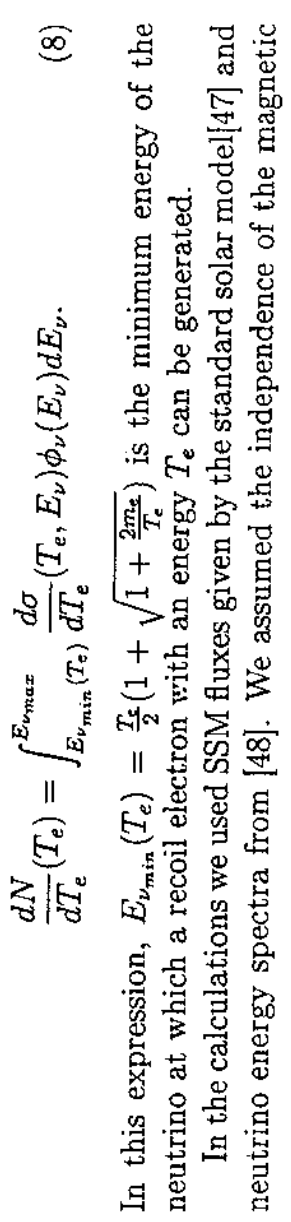



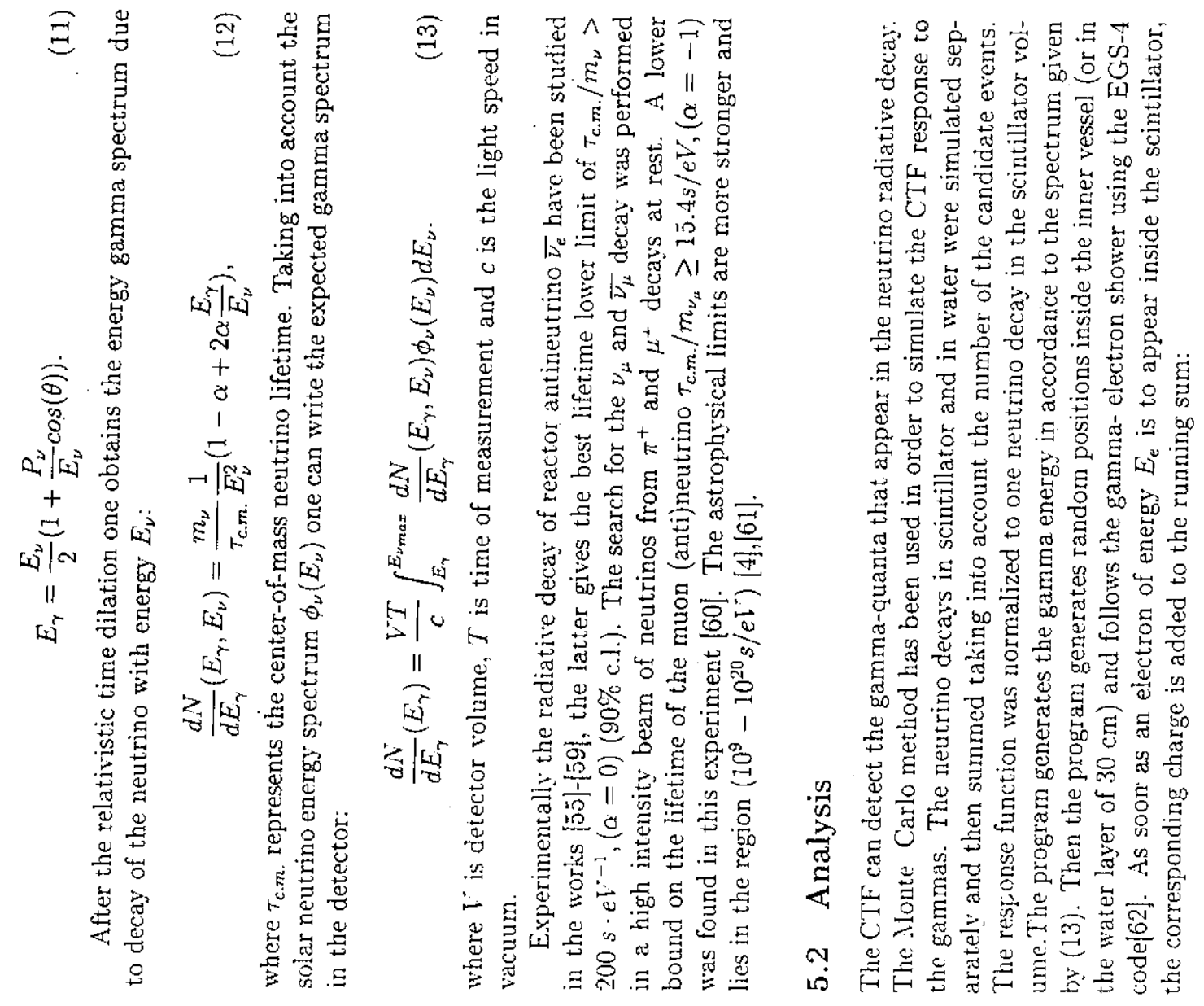

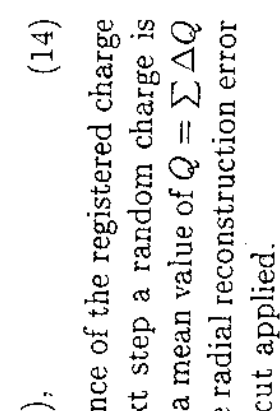

है

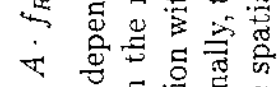

ऽั

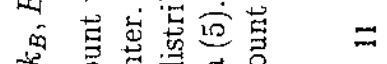

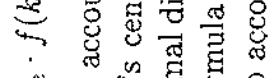

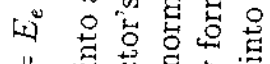

○.

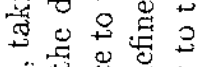

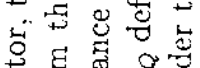

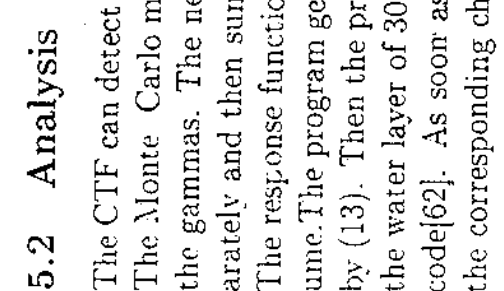

苟要要 80

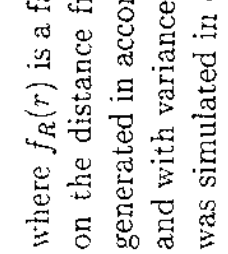
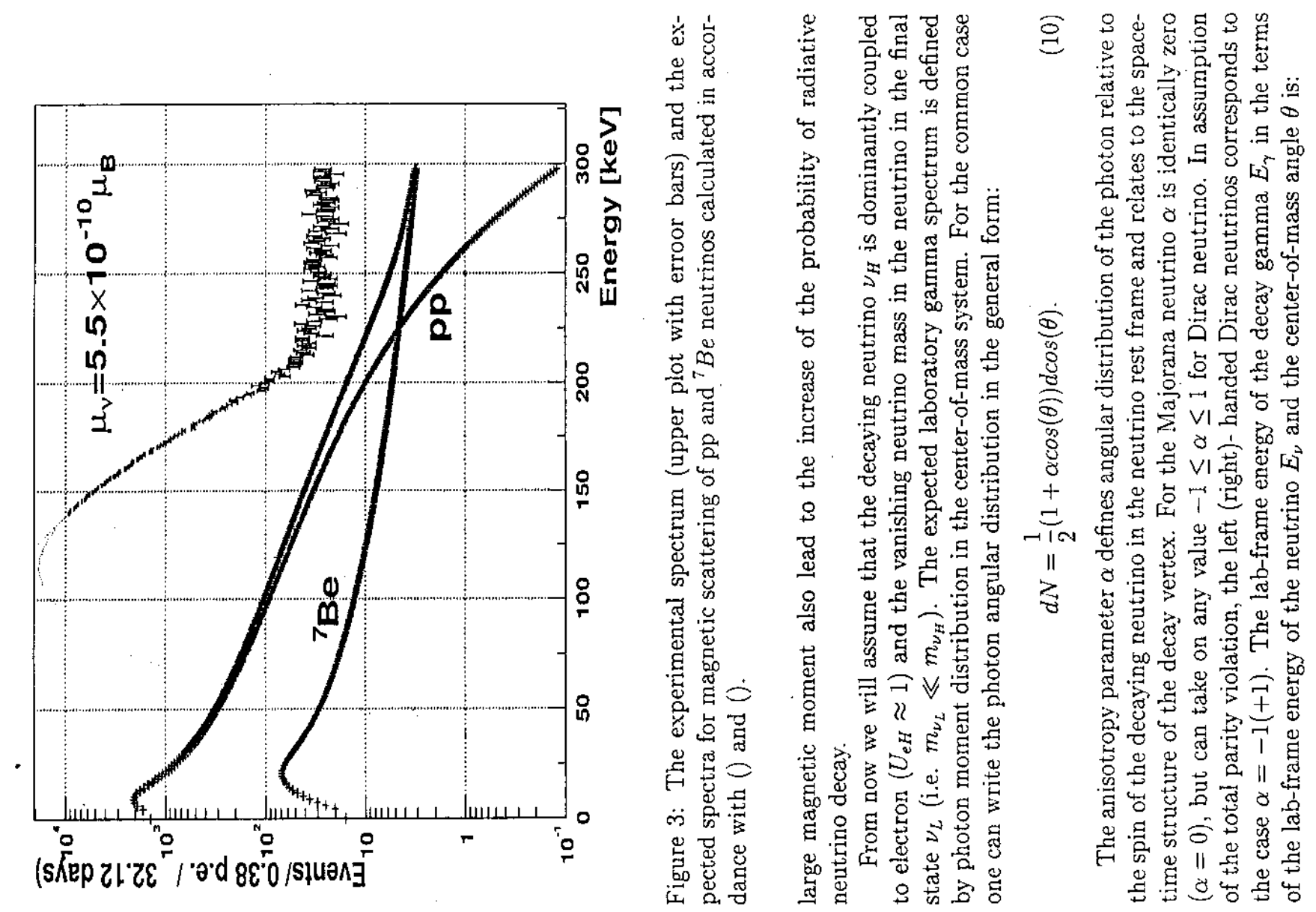
$\underset{7}{\frac{7}{2}} \frac{0}{8}$

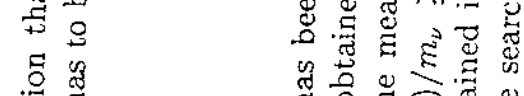

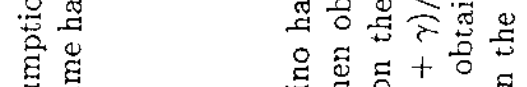

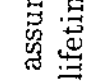

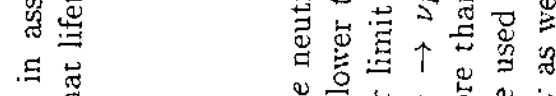

密空

峞

胥

点

䍆

की

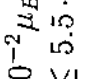

군

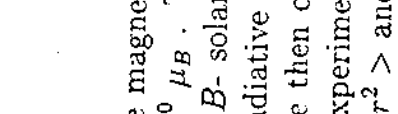

马.

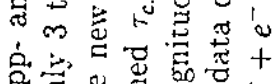

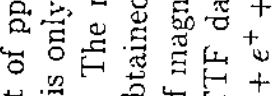

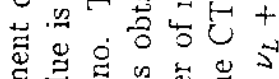

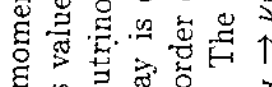

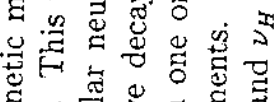

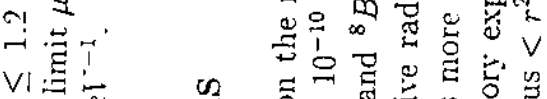

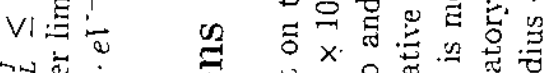

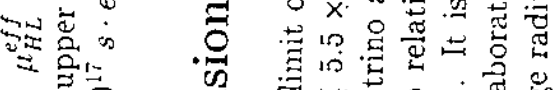

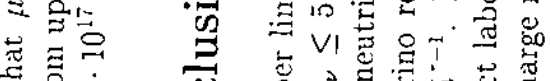

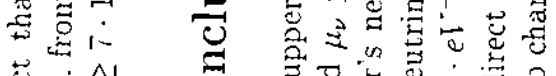

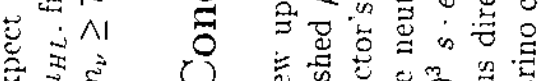

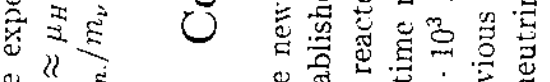

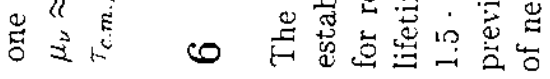

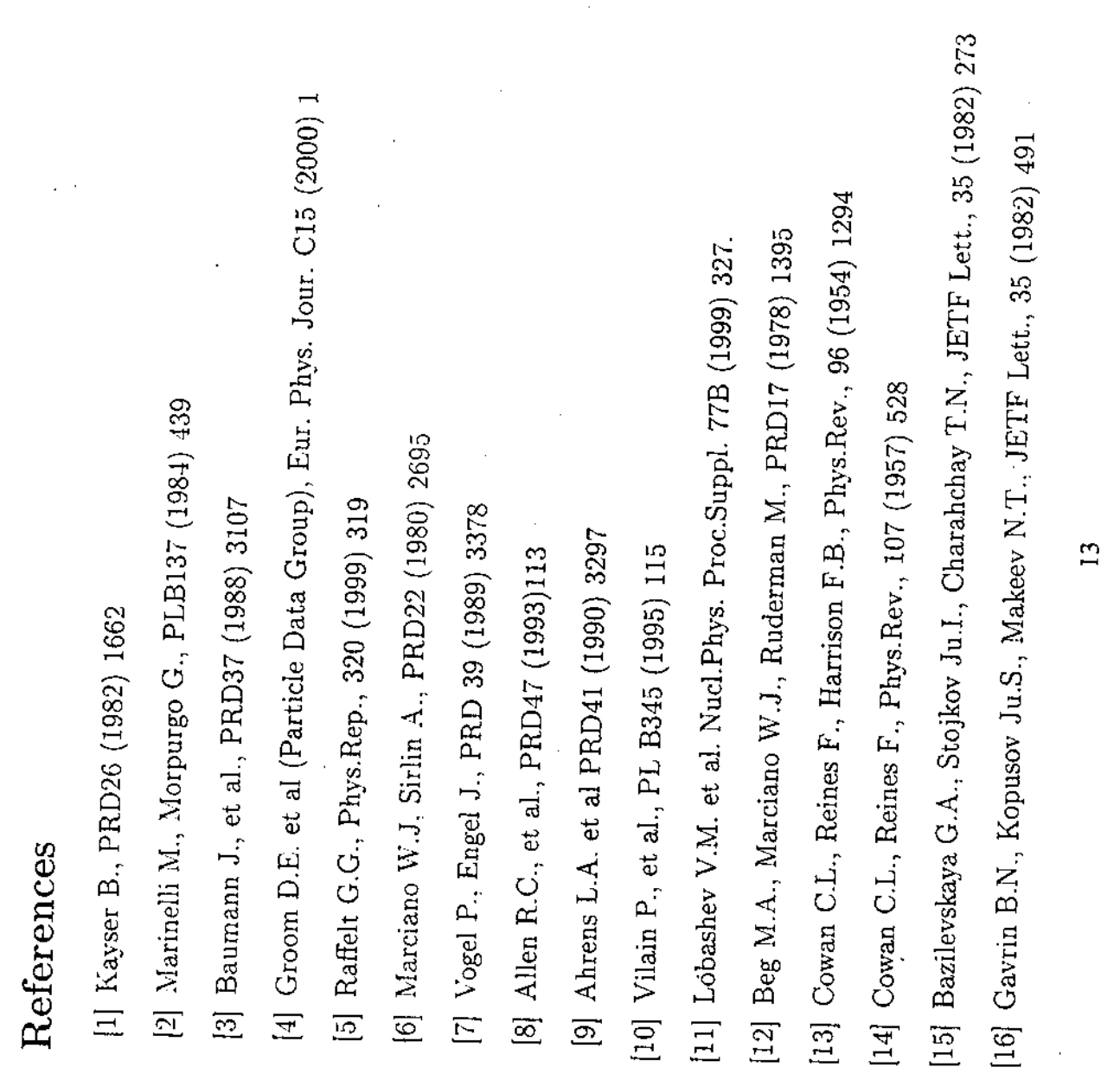

\& 8 is

통

वे क

总 궁음

हैं हैं

क

पे है

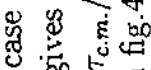

훙ㅁㅇ

형

क 31

\% 항 觉

空足

월

象敋点

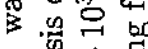

品家

쥬 $\wedge$ 능

त् है

㻤

过若

कह

可

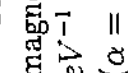

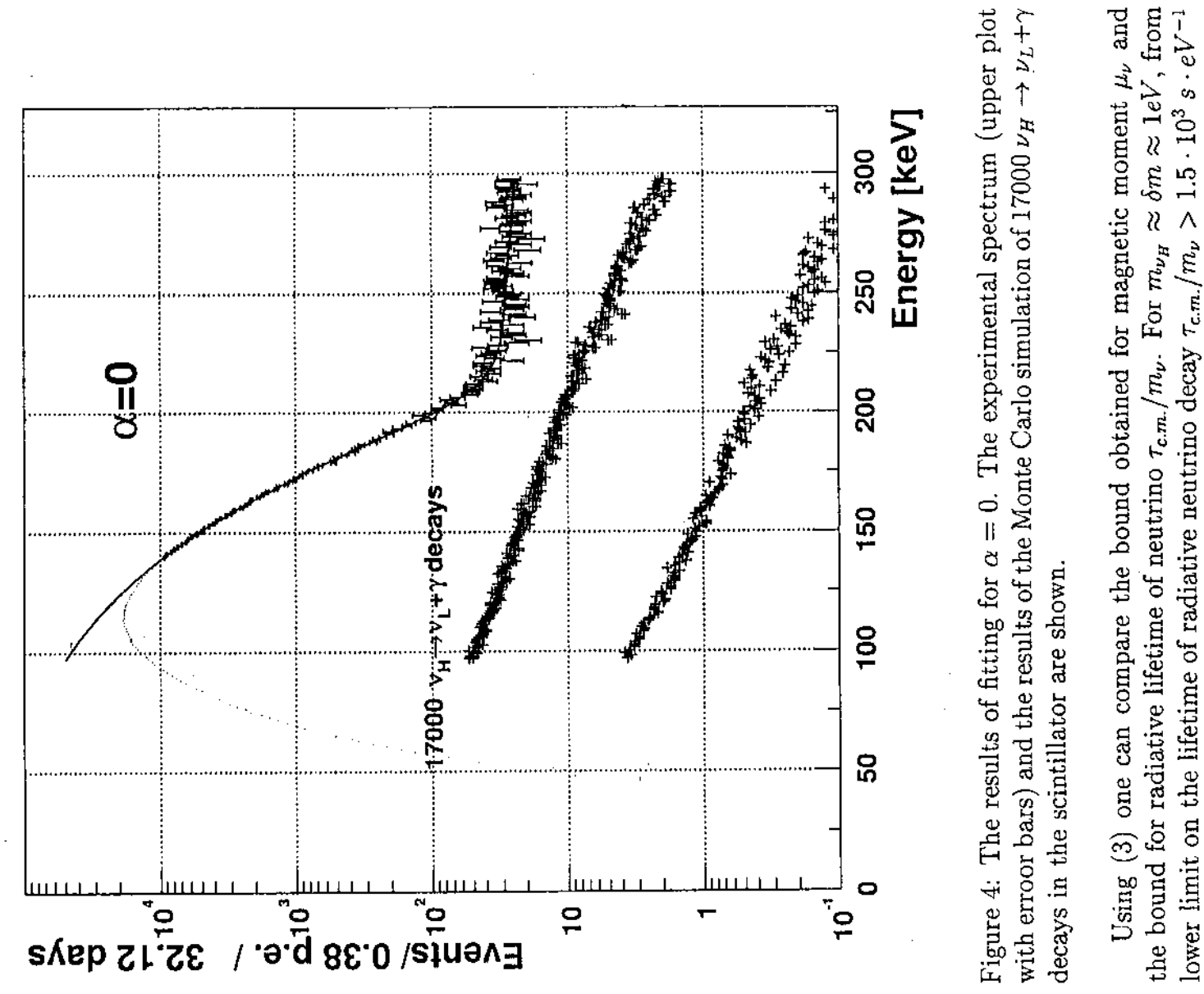



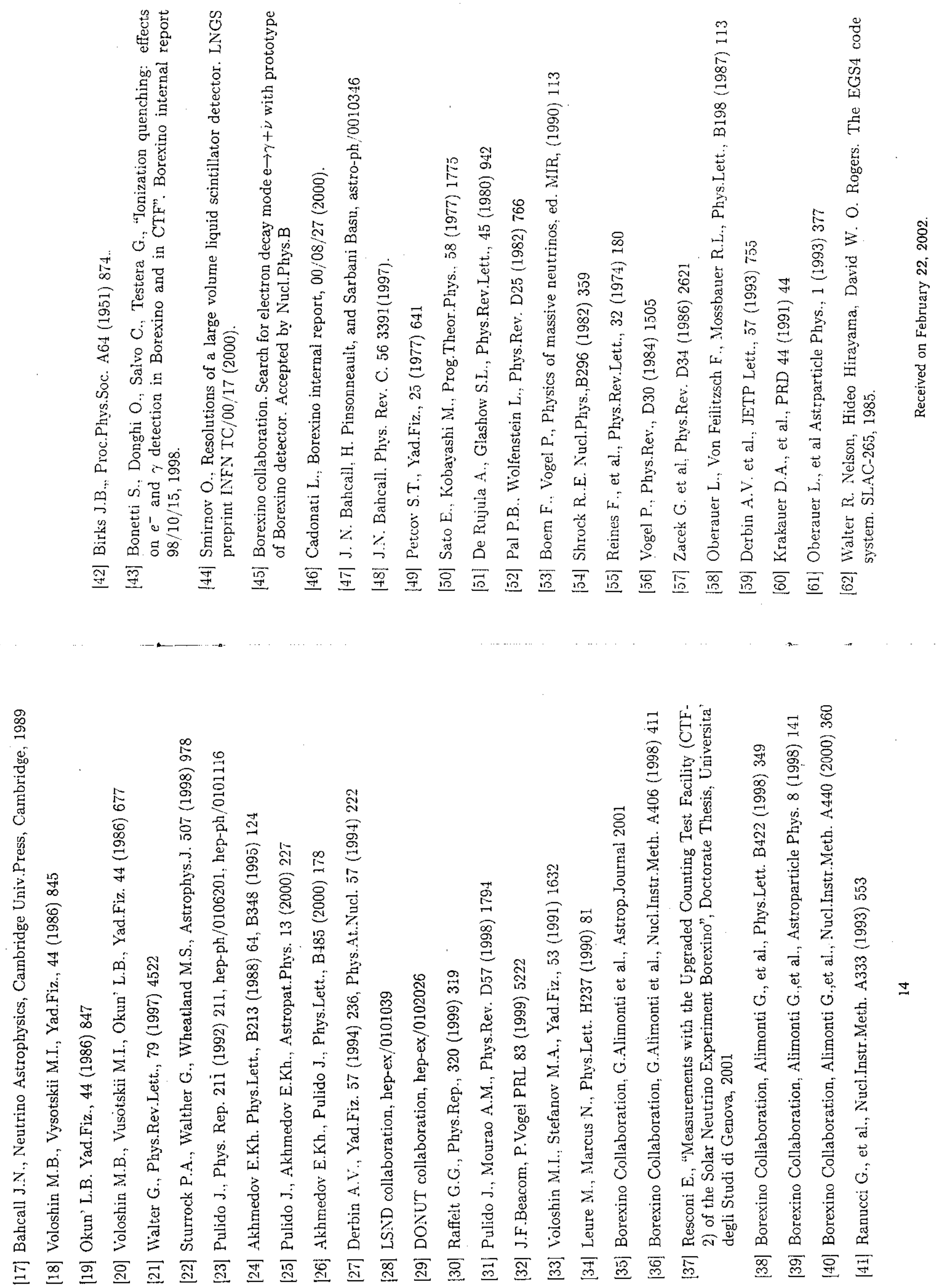

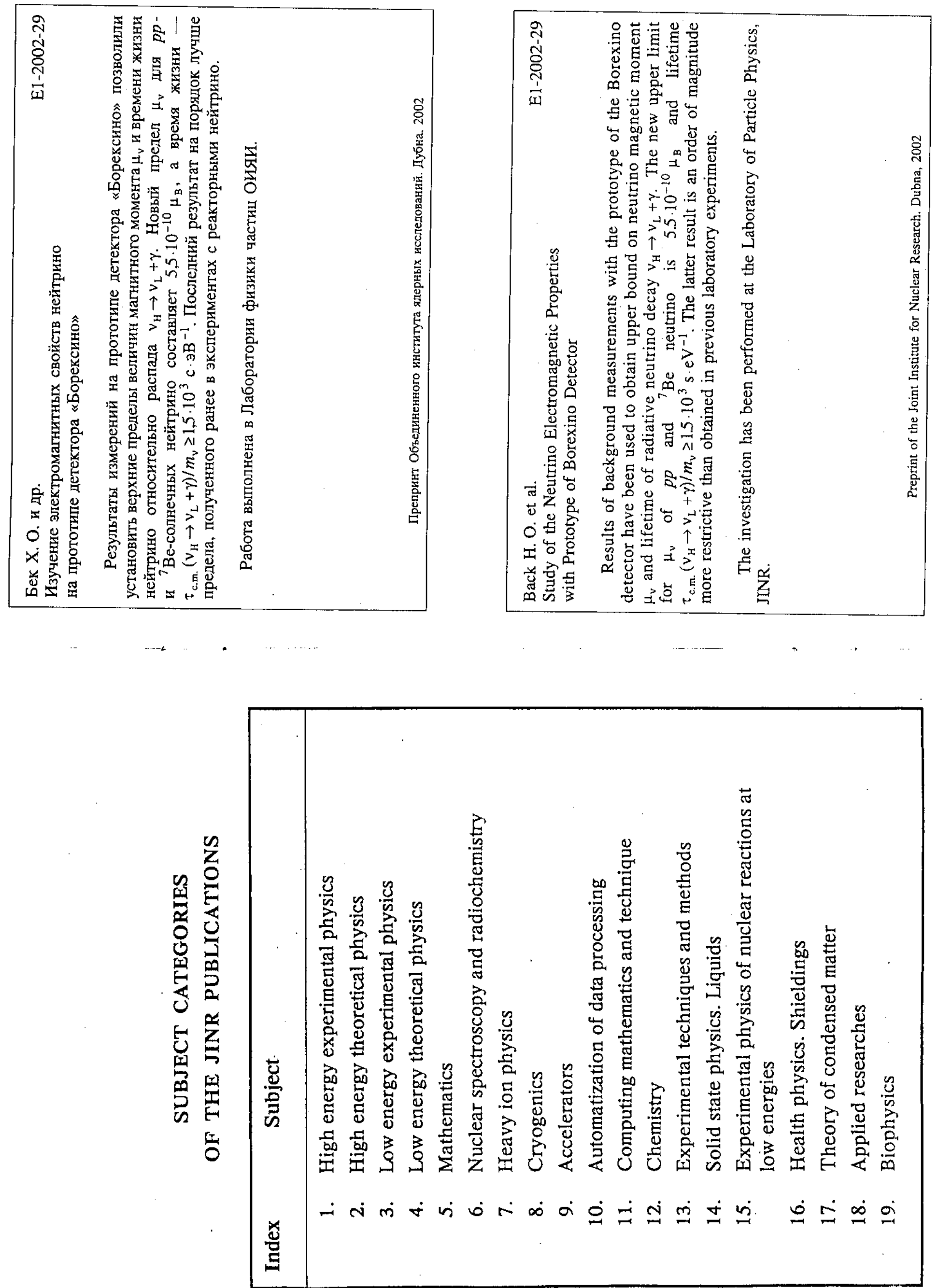


\section{Макет T. E. Попеко}

ЛР № 020579 от 23.06 .97 .

Подписано в печать 11.04.2002.

Формат $60 \times 90 / 16$. Бумага офсстная. Печать офсетная.

Усл. печ. л. І,18. Уч.-изд. л. І,9. Тираж 555 экз. Заказ № 53227.

Издательский отдел Объединенного института ядерных исследований

141980, г. Дубна, Московская обл., ул. Жолио-Кюри, 6. 